ADI WIDYA: Jurnal Pendidikan Dasar

FAKULTAS DHARMA ACARYA INSTITUT HINDU DHARMA NEGERI DENPASAR
Volume. 4, Nomor 2 Oktober 2019 ISSN: 2685-8312 (online)

ISSN: 2527-5445 (cetak

http://ejournal.ihdn.ac.id/index.php/AW

\title{
KETERAMPILAN DASAR DALAM \\ PROSES PEMBELAJARAN SISWA SEKOLAH DASAR Oleh
}

I Nyoman Sueca

inyomansueca64@gmail.com

Institut Hindu Dharma Negeri Denpasar, Indonesia

diterima 8 Agustus 2019, direvisi 17 September 2019, diterbitkan 1 Oktober 2019

\begin{abstract}
Abstrak
Pembelajaran adalah proses interaksi baik antara manusia dengan manusia ataupun antara manusia dengan lingkungan. Proses interaksi ini diarahkan untuk mencapai tujuan yang telah ditentukan, misalkan yang berhubungan dengan tujuan perkembangan kognitif, afektif dan psikomotor

Tercapainya perkembangan secara kognitif, afektif dan psikomotor sangat memerlukan keterampilan dasar sebagai keterampilan standar yang harus dimiliki setiap individu yang berprofesi sebagai guru. Keterampilan itulah yang sepintas dapat membedakan mana guru yang profesional dan mana yang bukan guru. Sama halnya dengan keterampilan seorang dokter dalam menggunakan alat suntik, atau seorang ahli bedah menggunakan pisau bedahnya. Sulit kita mengatakan bahwa ia seorang dokter, kalau ternyata tidak bisa menggunakan alat suntik, atau tidak bisa menulis resep. Keterampilan-keterampilan tersebut adalah keterampilan yang melekat pada profesinya sebagai hasil dari proses pendidikan yang diselenggarakan oleh lembaga pendidikan tertentu.

Dikaitkan dengan pembelajaran dalam konteks Kurikulum Berbasis Kompetensi, keterampilan dasar ini sangat penting untuk dikuasai oleh guru, kalau saat sekarang diberlakukan adalah kurikulum (K 13). Sebab strategi dan model pembelajaran apa pun yang digunakan efektivitasnya sangat ditentukan oleh keterampilan guru dalam pengelolaan proses pembelajaran. Banyak keterampilan yang harus dimiliki seorang guru agar dalam mengerjakan tugas profesionalnya berhasil secara optimal.
\end{abstract}

Kata kunci: Ketrampilan dasar dalam pembelajaran

\section{PENDAHULUAN}

Tercapainya

pembelajaran terletak pada kurikulum, tetapi bagnimanapun sempurna dan idealnya kurikulum, tanpa diimbangl kemampuan guru untuk mengimplementasikannya, maka kurikulum tersebut akan kurang bermakna. Demikian juga dengan keberadaan masa berlakunya Kurikulum Berbasis Kompetensi, hanya mungkin dapat diterapkan manakala guru secara profesional memiliki keterampilan 
ADI WIDYA: Jurnal Pendidikan Dasar

FAKULTAS DHARMA ACARYA INSTITUT HINDU DHARMA NEGERI DENPASAR
Volume. 4, Nomor 2 Oktober 2019

ISSN: 2685-8312 (online)

ISSN: 2527-5445 (cetak

http://ejournal.ihdn.ac.id/index.php/AW dalam pengelolaan pembelajaran atau dalam mengjar. Kita percaya bahwa mengajar adaloh pekerjaan profesional, sebagai pekerjaan profesional, orang yang menyandang pekerjaan tersebut mesti memiliki sejumlah keterampilan. Tentu saja keterampilan itu hanya mungkin didapatkan dari sebuah proses latihan dari lembaga pendidikan yang relevan, bukan semata-mata karena pembawaan. Mengapa dikatakan keterampilan dasar? Yang dimaksudkan keterampilan dasar adalah keterampilan standar yang harus dimiliki setiap individu yang berprofesi sebagai guru. Keterampilan itulah yang sepintas dapat membedakan mana guru yang profesional dan mana yang bukan guru. Sama halnya dengan keterampilan seorang dokter dalam menggunakan alat suntik, atau seorang ahli bedah menggunakan pisau bedahnya. Sulit kita mengatakan bahwa ia seorang dokter, kalau ternyata tidak bisa menggunakan alat suntik, atau tidak bisa menulis resep. Keterampilanketerampilan tersebut adalah keterampilan yang melekat pada profesinya sebagai hasil dari proses pendidikan yang diselenggarakan oleh lembaga pendidikan tertentu.

$$
\text { Dikaitkan dengan }
$$

pembelajaran dalam konteks Kurikulum Berbasis Kompetensi, keterampilan dasar ini sangat penting untuk dikuasai oleh guru, kalau sekarang adalah kurikulum (K
13). Sebab strategi dan model pembelajaran apa pun yang digunakan efektivitasnya sangat ditentukan oleh keterampilan guru dalam pengelolaan proses pembelajaran. Ada sejumlah keterampilan yang harus dimiliki seorang guru agar dalam mengerjakan tugas profesionalnya berhasil secara optimal.

Keterampilan dasar penguatan adalah segala bentuk respons yang merupakan bagian dari modifikasi. Tingkah laku guru terhadap tingkah laku siswa, yang bertujuan untuk memberikan informasi atau umpan balik bagi siswa atas perbuatan atau responnya yang diberikan sebagai suatu dorongan atau koreksi. Melalui keterampilan penguatan (reinforcement) yang diberikan guru, maka siswa akan merasa terdorong selamanya untuk memberikan respons setiap kali muncul stimulus dari guru; atau siswa akan berusaha menghindani respons yang dianggap tidak bermanfaat. Dengan demikian fungsi keterampilan penguatan (reinforcement) itu adalah untuk memberikan ganjaran kepada siswa sehingga siswa akan berbesar hati dan meningkatkan partisipasinya dalam setiap proses pembelajaran.

Pembelajaran adalah proses interaksi baik antara manusia dengan manusia ataupun antara manusia dengan 
ADI WIDYA: Jurnal Pendidikan Dasar

FAKULTAS DHARMA ACARYA INSTITUT HINDU DHARMA NEGERI DENPASAR
Volume. 4, Nomor 2 Oktober 2019 ISSN: 2685-8312 (online)

ISSN: 2527-5445 (cetak

http://ejournal.ihdn.ac.id/index.php/AW lingkungan. Proses interaksi ini diarahkan untuk mencapai tujuan yang telah ditentukan, misalkan yang berhubungan dengan tujuan perkembangan kognitif, afektif atau psikomotor. Tujuan pengembangan kognitif adalah proses pengembangan intelektual yang erat kaitannya dengan meningkatkan aspek pengetahuan, baik secara kuantitatif maupun kualitatif. Apa hakikat dari pengetahuan ini? Bagaimana sebenarnya setiap individu memperoleh pengetahuan?

Hal itu merupakan pertanyaanpertanyaan yang mendasar yang membutuhkan kajian filosofis.

Dilihat dari bagaimana pengetahuan itu dapat diperoleh manusia, dapat didekati dari dua pendekatan yang berbeda, yaitu pendekatan rasional dan pendekatan empiris. Rasionalisme menyatakan bahwa pengetahuan menunjuk kepada objek dan kebenaran itu merupakan akibat dari deduksi logis. Aliran rasionalis menekankan kepada rasio, logika, dan pengetahuan deduktif. Berbeda dengan aliran rasionalis, aliran empiris lebih menekankan kepada pentingnya pengalaman dalam memahami setiap objek. Aliran ini memandang bahwa semua kenyataan iu diketahui melalui indra dan kriteria kebenaran itu adalah kesesuaian dengan pengalaman. Dengan demikian pandangan empirisme menekankan kepada pengalaman dan pengetahuan induktif.

Apabila kita simak, baik aliran rasional maupun aliran empiris, keduanya berangkat dari dasar pemikiran yang sama, yaitu bahwa sumber utama dari pengetahuan adalah dunia luar atau objek yang ada di luar individu; atau objek yang menjadi pengamatannya. Yang menjadi masalah adalah, apakah pengetahuan itu semata-mata hanya terbentuk karena objek itu? Bukankah objek itu tidak akan memiliki arti apa-apa tanpa individu sebagai subjek yang menafsirkan data objektif itu? Apa artinya sebuah kenyataan tanpa interpretasi dan subjek? Apakah pengetahuan itu bersifat statis yang telah dihasilkan oleh pemikir terdahulu seperti yang diklaim oleh aliran idealisme?

Pertanyaan-pertanyaan semacam itu terus berkembang, dan menjadi bahan pemikiran manusia, hingga muncul aliran konstruktivisme yang berkembang selama abad dua puluh ini. Menurut aliran konstruktivisme, pengetahuan itu terbentuk bukan hanya dari objek semata, akan tetapi juga dari kemampuan individu sebagai subjek yang menangkap setiap objek yang diamati. Menurut konstruktivisme oleh dan dari dalam diri seseorang. Oleh sebab itu, pengetahuan 
ADI WIDYA: Jurnal Pendidikan Dasar

FAKULTAS DHARMA ACARYA INSTITUT HINDU DHARMA NEGERI DENPASAR

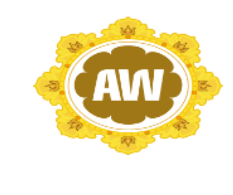

Volume. 4, Nomor 2 Oktober 2019 ISSN: 2685-8312 (online)

ISSN: 2527-5445 (cetak

http://ejournal.ihdn.ac.id/index.php/AW terbentuk oleh dua faktor penting, yaitu objek yang menjadi bahan pengamatan dan kemampuan subjek untuk menginterpretasi objek tersebut. Kedua faktor itu sama pentingnya. Dengan demikian pengetahuan itu tidak bersifat statis, akan tetapi bersifat dinamis, tergantung individu yang melihat dan mengonstruksinya. Inilah dasar filosofis dalam pembelajaran berpikir. Selanjutnya tentang hakikat pengetahuan menurut filsafat konstruktivisme adalah sebagai berikut:

a. Pengetahuan bukanlah merupakan gambaran dunia kenyataan belaka, akan tetapi selalu merupakan konstruksi kenyataan melalui subjek.

b. Subjek membentuk skema kognitif, kategori, konsep, dan struktur yang perlu untuk pengetahuan.

c. Pengetahuan dibentuk oleh struktur konsepsi seseorang. Struktur konsepsi membentuk pengetahuan bila konsepsi itu berhadapan dengan pengalamanpengalamari seseorang (Suparno, 1997:21).

Sesuai dengan penjelasan di atas, maka dalam proses pembelajaran berpikir, pengetahuan tidak diperoleh sebagai hasil transfer dan orang lain, akan tetapi pengetahuan diperoleh melalui interaksi mereka dengan objek, fenomena, pengalaman, dan lingkungan yang ada. Suatu pengetahuan dianggap benar, manakala pengetahuan tersebut berguna untuk menghadapi dan memecahkan persoalan atau fenomena yang muncul. Aliran konstruktivisme menganggap bahwa pengetahuan tidak dapat ditransfer begitu saja dari seseorang kepada orang lain, tetapi harus diinterpretasikan sendiri oleh masing-masing individu. Oleh sebab itu, model pembelajaran berpikir menekankan kepada aktivitas siswa unuk mencari pemahaman akan objek, menganalisis dan mengonstruksinya sehingga terbentuk pengetahuan baru dalam diri individu.

\section{PEMBAHASAN}

Menurut Wragg (dalam Sanjaya,2006:156) dari sejumlah keterampilan tersebut dapat diperas menjadi beberapa keterampilan. Mengapa dapat diperas? Ya, dapat diperas, oleh sebab dalam keterampilan-keterampilan tertentu dapat dilakukan dalam satu situasi. Beberapa keterampilan dasar yang dianggap sangat penting dan dianggap dapat menunjang dalam implementasi Kurikulum dijelaskan di bawah ini: 
ADI WIDYA: Jurnal Pendidikan Dasar

FAKULTAS DHARMA ACARYA INSTITUT HINDU DHARMA NEGERI DENPASAR
Volume. 4, Nomor 2 Oktober 2019

ISSN: 2685-8312 (online)

ISSN: 2527-5445 (cetak

http://ejournal.ihdn.ac.id/index.php/AW
Keterampilan Dasar Bertanya (Questioning)

Keterampilan bertanya, bagi seorang guru merupakan keterampilan yang sangat penting untuk dikuasai. Mengapa demikian? Sebab melalui keterampilan ini guru dapat menciptakan suasana pembelajaran lebih bermakna. Dapat kita rasakan, pembelajaran akan menjadi sangat membosankan, manakala selama berjam-jam guru menjelaskan materi pelajaran tanpa diselingi dengan pertanyaan, baik hanya sekadar pertanyaan pancingan, atau pertanyaan untuk mengajak siswa berpikir. Oleh karena itu dalam setiap proses pembelajaran, model pembelajaran apa pun yang digunakan bertanya merupakan kegiatan yang selalu merupakan bagian yang tidak terpisahkan. Para ahli percaya, pertanyaan yang baik, memiliki dampak yang positif terhadap siswa, di antaranya:

a. Dapat meningkatkan partisipasi siswa secara penuh dalam proses pembelajaran.

b. Dapat meningkatkan kemampuan berpikir siswa, sebab berpikir itu sendiri pada hakikataya bertanya. c. Dapat membangkitkan rasa ingin tahu siswa, serta menuntun siswa untuk menentukan jawaban.

d. Memusatkan siswa pada masalah yang sedang dibahas.

Dalam penerapan modelmodel pembelajaran baik CTL apalagi model pembelajaran peningkatan kemampuan berpikir (MP PKB), keberhasilannya sangat ditentukan oleh keterampilan bertanya. Mengapa demikian? Oleh sebab model-model pembelajaran yang demikian tidak menempatkan siswa sebagai objek belajar yang hanya bertugas mendengarkan, mencatat, dan menghafal materi pelajaran. Akan tetapi mendorong siswa untuk berperan secara aktif dalam mencari dan menemukan sendiri pengetahuannya. Bagaimana proses mendorong siswa untuk menemukan itu akan sangat dipengaruhi oleh kemampuan guru dalam membimbing siswa melalui proses bertanya.

Mengingat begitu pentingnya peranan bertanya dalam proses pembelajaran, maka setiap guru harus memiliki keterampilan ini, untuk menjamin kualitas pembelajaran. Di bawah ini dijelaskan tentang jenis-jenis pertanyaan, dan teknik-teknik bertanya. 
ADI WIDYA: Jurnal Pendidikan Dasar

FAKULTAS DHARMA ACARYA INSTITUT HINDU DHARMA NEGERI DENPASAR

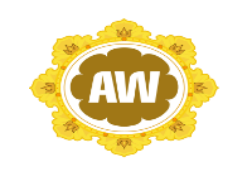

Volume. 4, Nomor 2 Oktober 2019 ISSN: 2685-8312 (online)

ISSN: 2527-5445 (cetak

http://ejournal.ihdn.ac.id/index.php/AW
1. JENIS-JENIS PERTANYAAN Pertanyaan itu banyak jenisnya. Dilihat dari maksudnya, pertanyaan terdiri dari:

a. Pertanyaan permintaan (compliance question), yaitu pertanyaan yang mengandung unsur suruhan dengan harapan agar siswa dapat mematuhi perintah yang diucapkan, oleh karena itu pertanyaan ini tidak mengharapkan jawaban dari siswa, akan tetapi yang diharapkan adalah tindakan siswa.

\section{Contoh:}

Dapatkah kamu menunjukkan batas-batas wilayah Provinsi di Indonesia pada peta yang ada di depanmu?

Pertanyaan semacam itu, bukanlah pertanyaan yang perlu dijawab "ya" atau "tidak". Akan tetapi pertanyaan yang menuntut tindakan siswa.

b. Pertanyaan retoris (rhetorical question), yakni jenis pertanyaan yang tidak menghendaki jawaban dari siswa, akan tetapi kita sendiri yang menjawabanya.

\section{Contoh:}

Mengapa manusia perlu makanan? Ya, disebabkan setiap manusia memerlukan energi, dan energi bersumber dari makanan....

Dari contoh tersebut, sebenarnya kita ingin mengungkapkan bahwa makanan merupakan sumber energi yang dibutuhkan oleh manusia. Akan tetapi, penjelasan yang didahului oleh pertanyaan retoris seperti di atas, proses komunikasi dengan siswa lebih bertenaga.

c. Pertanyaan mengarahkan atau menuntun (prompting question), adalah pertanyaan yang ditujukan untuk menuntun proses berpikir siswa, dengan harapan siswa dapat memperbaiki atau menemukan jawaban yang lebih tepat dari jawaban sebelumnya.

Contoh:

Guru : Mengapa
manusia memerlukan
pendidikan?
Siswa $\quad$ Karena
pendidikan itu dapat
mencerdaskan bangsa.

d. Pertanyaan menggali (probing question), adalah pertanyaan yang diarahkan untuk mendorong siswa agar dapat menambah kualitas dan kuantitas jawaban. Jenis pertanyaan ini sangat penting untuk meningkatkan kemampuan berpikir siswa. Contoh:

Guru : Mengapa setiap manusia memerlukan pendidikan?

Siswa : Karena negara membutuhkan bangsa cerdas

Guru : Lalu, apa hubungannya antara kecerdasan dengan pembangunan? 
ADI WIDYA: Jurnal Pendidikan Dasar

FAKULTAS DHARMA ACARYA INSTITUT HINDU DHARMA NEGERI DENPASAR
Volume. 4, Nomor 2 Oktober 2019 ISSN: 2685-8312 (online)

ISSN: 2527-5445 (cetak

http://ejournal.ihdn.ac.id/index.php/AW
Sekarang pertanyaan dilihat dari tingkat kesulitan jawaban yang diharapkan bisa terdiri dari pertanyaan tingkat rendah dan pertanyaan tingkat tinggi.

e. Pertanyaan pengetahuan (kownedge question)

Pertanyaan ini merupakan pertanynan yang memiliki tingkat kesulitan yang paling rendah, karena hanya mengandalkan kemampuan mengingat fakta atau data, oleh sebab itu dinamakan juga pertanyaan yang menghendaki agar siswa dapat mengungkapkan kembali (recall question).

Contoh:

Kapan perang Diponegoro ber1 angung?

Sebutkan Ibu Kota Negara Malaysia?

Siapa presiden wanita Indonesia?

Jawaban dan jenis pertanyaan seperti itu sangat sederhana, bukan? Ya, karena kesederhanaan jawaban itulah, dilihat dari tingkat kesulitannya, pertanyaan tersebut tergolong pada pertanyaan tingkat rendah.

f.Pertanyaan pemahaman (comprehension question)

Dilihat dari tingkat kesulitan jawaban yang diharapkan, pertanyaan pemahaman lebih sulit dibandingkan dengan pertanyaan jenis pertama, oleh sebab pertanyaan ini tidak hnnya sekadar mengharapkan siswa untuk mengungkapkan kembali apa yang diingatnya, akan tetapi pertanyaan yang mengharapkan kemampuan siswa untuk memperjelas gagasan.

Contoh:

Bandingkan apa perbedaan antara tumbuhan yang berkembang biak dengan cara generatif dan vegetatif?

Untuk menjawab pertanyaan tersebut, siswa dituntut bukan hanya sekadar tahu akan kedua konsep di atas, akan tetapi siswa harus dapat lebih mendalami keduanya, sebab kemampuan membandingkan harus didahului oleh kemampuan menyebutkan indikator-indikatornya.

Contoh lain:

Jelaskan apa yang disebut dengan pernafasan aerob dan anaerob?

g. Pertanyaan aplikatif
(aplication question)
Adalah pertanyaan menghendaki jawaban agar siswa dapat menerapkan pengetahuan yang telah dimilikinya.

Contoh:

Kamu telah belajar bagaimana cara menghitung luas sebuah bidang. Nah, sekarang coba kamu hitung berapa luas kelas tempat belajar kita ini.

h. Pertanyaan analisis (Analysis question)

Pertanyaan analisis adalah pertanyaan yang menghendaki agar siswa dapat menguraikan suatu konsep tertentu.

\section{Contoh:}

Coba Anda uraikan dengan jelas apa fungsi jantung? 
ADI WIDYA: Jurnal Pendidikan Dasar

FAKULTAS DHARMA ACARYA INSTITUT HINDU DHARMA NEGERI DENPASAR

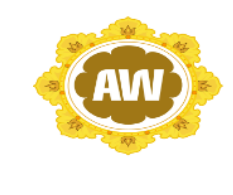

Volume. 4, Nomor 2 Oktober 2019 ISSN: 2685-8312 (online)

ISSN: 2527-5445 (cetak

http://ejournal.ihdn.ac.id/index.php/AW i. Pertanyaan sintesis (synthesis question)

Pertanyaan jenis ini menghendaki agar siswa dapat membuat semacam ringkasan melalui bagan dan suatu kajian materi pembelajaran.

\section{Contoh:}

Kita telah mempelajari tentang raja-raja yang pernah berkuasa di Majapahit. Sekarang coba kamu buat bagan tentang silsilah tersebut.

j. Pertanyaan evaluasi (evaluation question), adalah pertanyaan yang menghendaki jawaban dengan cara memberikan penilaian atau pendapatnya terhadap suatu isu.

Contoh:

Bagaimana pendapatmu tentang pelaksanaan program Keluarga Berencana?

\section{k. TEKNIK-TEKNIK BERTANYA}

Sekarang, bagaimana agar proses bertanya yang kita laksanakan dapat berhasil membelajarkan siswa? Kita harus paham bagaimana cara bertanya yang baik. Beberapa saran dalam teknik bertanya atau menerima jawaban dari pertanyaan yang kita ajukan dijelaskan herikut ini.

\section{a. Beberapa Petunjuk Teknis}

1) Tunjukkan keantusiasan dan kehangatan

Yang dimaksud dengan kehangatan dan keantusiasan adalah cara

guru mengekspresikan pertanyaan atau menjawab pertanyaan, misalnya bahasa yang digunakan tidak terkesan memojokkan siswa, mimik atau wajah yang hangat tidak terkesan tegang, tapi akrab dan bersahabat dengan sedikit Senyuman dan lain sebagainya; tidak mencibir atau memelototi siswa. Sikap semacam ini sangat perlu, sebab dapat memunculkan keberanian siswa untuk berintuisi, keberanian siswa untuk menduga dan akhirnya keberanian siswa untuk berpikir dan berargumen.

2) Berikan waktu secukupnya kepada siswa untuk berpikir

Salah satu kelemahan guru yang sering terjadi adalah ketidaksabaran untuk segera menemukan jawaban yang sesuai dengan harapan guru. Oleh karenanya, guru sering menjawab sendiri pertanyaan yang diajukan, sehingga pada akhirnya pertanyaan tersebut sama sekali tidak memiliki makna untuk membelajarkan siswa. Oleh karena itu dalam proses bertanya, guru perlu memberikan kesempatan yang cukup bagi siswa untuk menemukan jawaban yang tepat. Guru harus menghindari untuk menjawab sendiri pertanyaan yang diajukan. Biarkan siswa mencari, menduga, dan bereksplorasi untuk menemukan jawaban sesuai dengan kemampuannya.

3) Atur lalu lintas bertanya jawab 
ADI WIDYA: Jurnal Pendidikan Dasar

FAKULTAS DHARMA ACARYA INSTITUT HINDU DHARMA NEGERI DENPASAR

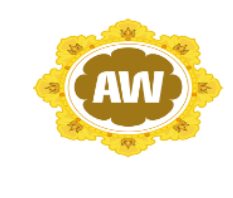

Volume. 4, Nomor 2 Oktober 2019 ISSN: 2685-8312 (online)

ISSN: 2527-5445 (cetak

http://ejournal.ihdn.ac.id/index.php/AW
Sering terjadi khususnya di sekolah-sekolah tingkat dasar, ketika guru bertanya, secara bersama-sama siswa menjawab serempak pertanyaan yang diajukan sehingga sulit menangkap makna jawaban yang diberikan guru. Hal ini tentu saja bukan cara yang bagus, sebab proses tanya jawab hanya membuangbuang waktu. Sebaiknya guru harus dapat mengatur proses tanya jawab. Artinya, setelah pertanyaan diberikan kepada seluruh kelas, aturlah siapa yang pantas memberikan jawaban, suruh yang lain menyimak jawaban tersebut dan memberikan komentar.

4) Hindari pertanyaan ganda

Pertanyaan ganda adalah pertanyaan yang mengharapkan beberapa jawaban sekaligus. Pertanyaan semacam ini akan membingungkan siswa, sehingga akan mengganggu proses berpikir siswa karena tidak fokus terhadap arah pertanyaan yang diajukan. Misalnya guru bertanya: "Faktorfaktor apa yang menyebabkan timbulnya arus urbanisasi dan apa akibatnya terhadap kehidupan sosial?" Pertanyaan tersebut jelas membingungkan dan akan menyulitkan siswa untuk menemukan jawaban yang tepat karena siswa harus berpikir zigzag.

\section{b. Meningkatkan Pertanyaan}

Kualitas

Di samping beberapa petunjuk secara teknis, dalam teknik bertanya juga perlu diperhatikan bagaimana meningkatkan kualitas pertanyaan agar mampu menjadi alat untuk meningkatkan kemampuan berpikir dan meningkatkan kualitas pembelajaran bagi siswa.

1) Berikan pertanyaan secara berjenjang

Yang dimaksud pertanyaan secara berjenjang adalah pengaturan pertanyaan yang dimulai dari pertanyaan tingkat rendah ke pertanyaan tingkat tinggi. Artinya sebaiknya dalam memberikan pertanyaan diawali dengan pertanyaan mengingat, lalu pertanyaan pemahaman, penerapan, dan seterusnya. Hal ini sangat penting untuk meningkatkan mental berpikir siswa. Guru harus menghindari pertanyaan yang bolak-balik. Misalnya, dalam satu bahasan tertentu guru mengajukan pertanyaan ingatan untuk menghafal fakta, kemudian dilanjutkan dengan pertanyaan analisis, kembali lagi ke pertanyaan pemahaman, dan seterusnya. Pertanyaan yang bolakbalik semacam itu akan mengakibatkan keruwetan berpikir siswa.

2) Gunakan pertanyaan-pertanyaan untuk melacak

Pertanyaan-pertanyaan yang sifatnya melacak sangat diperlukan untuk meningkatkan kualitas bertanya sebagai alat pembelajaran. Beberapa hal yang berkaitan dengan pertanyaan melacak di antaranya: (1) Ketika guru mendapatkan 
ADI WIDYA: Jurnal Pendidikan Dasar

FAKULTAS DHARMA ACARYA INSTITUT HINDU DHARMA NEGERI DENPASAR
Volume. 4, Nomor 2 Oktober 2019

ISSN: 2685-8312 (online)

ISSN: 2527-5445 (cetak

http://ejournal.ihdn.ac.id/index.php/AW jawaban siswa dengan struktur kalimat yang rancu atau tidak jelas, maka guru dapat mengajukan pertanyaan yang mengharapkan siswa memperbaiki kalimat yang diajukan.

(2)Ketika siswa menjawab berdasarkan alur pikiran atau pandangan menurut siswa sendiri, maka guru dapat mengajukan pertanyaan agar siswa dapat memberikan argumentasi yang tepat dari siswa.

(3)Ketika siswa menjawab belum lengkap sesuai dengan konsep yang benar, maka guru dapat membimbing agar siswa memberikan jawaban yang lengkap. Dalam hal ini dapat juga diteruskan dengan pertanyaanpertanyaan yang dapat mendorong siswa memberikan ilustrasi dan contoh-contoh yang konkret.

\section{JENIS-JENIS PENGUATAN}

Ada dua jenis penguatan yang bisa diberikan oleh guru yaitu penguatan verbal dan non-verbal.

a. Penguatan Verbal

Penguatan verbal adalah penguatan yang diungkapkan dengan kata-kata baik kata-kata pujian dan penghargaan atau katakata koreksi. Melalui kata-kata itu siswa akan merasa tersanjung dan berbesar hati sehingga ia akan merasa puas dan terdorong untuk lebih aktif belajar. Misalnya ketika diajukan sebuah pertanyaan kemudian siswa menjawab dengan tepat, maka guru memuji siswa tersebut dengan mengatakan: "Bagus..!" atau "Tepat sekali". "Wah ... hebat kamu", dan lain sebagainya. Demikian juga ketika jawaban siswa kurang sempurna, guru berkata: "Hampir tepat..." atau "Seratus kurang lima puluh...", dan lain sebagainya. Apa yang diungkapkan guru menunjukkan bahwa jawaban siswa masih perlu penyempumaan.

b. Penguatari Non-Verbal

Penguatan non-verbal adalah penguatan yang diungkapkan melalui bahasa isyarat. Misalnya melalui anggukan kepala tanda setuju, gelengan kepala tanda tidak setuju, mengernyitkan dahi, mengangkat pundak, dan lain sebagainya. Selain itu penguatan nonverbal juga bisa dilakukan dengan memberikan tanda-tanda tertentu misalnya penguatan dengan melakukan sentuhan (contact) dengan berjabat tangan atau menepuk-nepuk pundak siswa setelah siswa memberikan respons yang bagus.

\section{TEKNIK MEMBERIKAN PENGUATAN}

Terdapat beberapa hal yang harus diperhatikan dalam memberikan penguatan agar penguatan itu dapat meningkatkan

motivasi pembelajaran.

a. Kehangatan dan Keantusiasan Ketika guru memberikan penguatan, tunjukkan sikap yang hangat dan antusias, bahwa penguatan itu 
ADI WIDYA: Jurnal Pendidikan Dasar

FAKULTAS DHARMA ACARYA INSTITUT HINDU DHARMA NEGERI DENPASAR
Volume. 4, Nomor 2 Oktober 2019

ISSN: 2685-8312 (online)

ISSN: 2527-5445 (cetak

http://ejournal.ihdn.ac.id/index.php/AW benar-benar diberikan sebagai balasan atas respons yang diberikan siswa. Hindari kepura-puraan, atau tindakan penguatan yang mengadaada.

b. Kebermaknaan

Yakinkan pada diri siswa bahwa penguatan yang diberikan guru adalah penguatan yang wajar, sehingga benar-benar bermakna untuk siswa. Hindari penguatan yang berlebihan, sebab penguatan yang demikian justru akan mematikan motivasi siswa. Siswa hanya akan merasa direndahkan.

\section{c. Gunakan Penguatan yang Bervariasi}

Penguatan yang sejenis dan dilakukan berulang-ulang, dapat menimbulkan kebosanan sehingga tidak efektif lagi untuk membangkitkan motivasi belajar siswa. Oleh sebab itu, penguatan perlu dilakukan dengan teknik yang bervariasi. Sekali-kali gunakan penguatan dengan bahasa verbal; dan lain kali gunakan dengan gerakangerakan.

\section{d. Berikan Penguatan dengan Segera}

Penguatan perlu diberikan segera setelah muncul respons atau tingkah laku tertentu. Penguatan yang ditunda pemberiannya tidak akan efektif lagi dan kurang bermakna.

\section{Keterampilan Dasar Variasi Stimulus (Variation Stimulus)}

Dalam suatu kegiatan pembelajaran siswaa merasa bosan, jenuh, kurang bergairah, bahkan mengantuk? Biasanya munculnya kondisi semacam itu disebabkan penyajian guru yang tidak menarik, sehingga siswa menginginkan agar proses pembelajaran cepat usai. Untuk menghindari kebosanan siswa dalam proses pembelajaran, guru perlu memiliki keterampilan variasi stimulus.

Variasi stimulus adalah keterampilan guru untuk menjaga agar iklim pembelajaran tetap menarik perhatian, tidak membosankan, sehingga siswa menunjukkan sikap antusias dan ketekunan, penuh gairah dan berpartisipasi aktif dalam setiap langkah kegiatan pembelajaran. Dalam model-model pembelajaran sebagai implementasi Kurikulum Berbasis Kompetensi, keterampilan ini sangat diperlukan bagi setiap guru. Sebab, Kurikulum Berbasis Kompetensi mengharapkan siswa berpartisipasi aktif dalam setiap tahapan proses pembelajaran. Dalam konteks inilah guru perlu menjaga agar iklim belajar tetap kondusif dan menyenangkan.

Dalam suatu
pembelajaran $\begin{gathered}\text { proses } \\ \text { bisa }\end{gathered}$
terjadi
disebabkan oleh suara guru,
mungkin terlalu lemah sehingga
suaranya tidak bisa ditangkap
oleh seluruh siswa; atau
pengucapan kalimat yang kurang
jelas (ngosom). Guru yang baik
akan, terampil mengatur volume


ADI WIDYA: Jurnal Pendidikan

Dasar

FAKULTAS DHARMA ACARYA

INSTITUT HINDU DHARMA NEGERI DENPASAR
Volume. 4, Nomor 2 Oktober 2019

ISSN: 2685-8312 (online)

ISSN: 2527-5445 (cetak

http://ejournal.ihdn.ac.id/index.php/AW

adalah berbagai
macam peragaan,
model, dan lain
sebagainya.

a. Variasi dalam Berinteraksi

Pembelajaran adalah proses interaksi antara siswa dengan lingkungannya. Guru perlu membangun interaksi secara penuh dengan memberikan kesempatan seluas-luasnya kepada siswa untuk berinteraksi dengan lingkungannya. Kesalahan yang sering terjadi selama proses pembelajaran

- Pola Interaksi Satu Arah

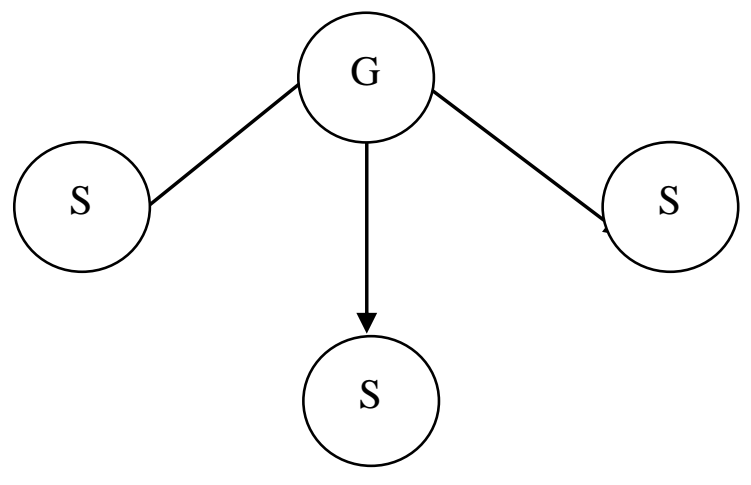

Pola Interaksi Dua Arah

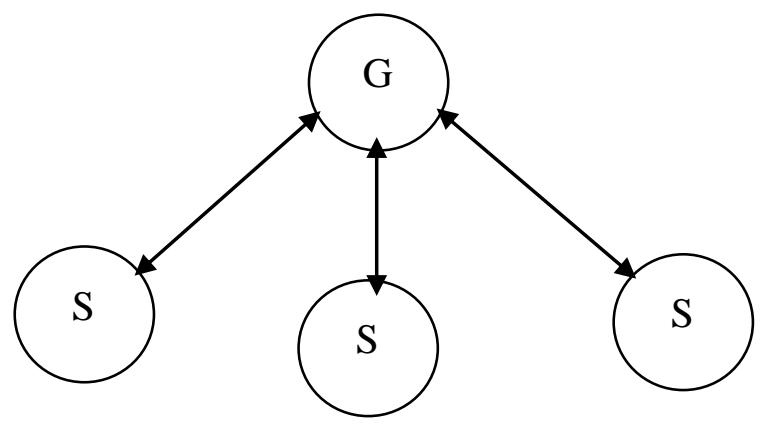

berlangsung guru hanya menggunakan pola interaksi satu arah, yaitu dari guru ke siswa. Pola interaksi yang demikian, bukan hanya dapat membuat iklim pembelajaran menjadi statis akan tetapi dapat memasung kreativitas siswa. Oleh sebab itu, guru perlu menggunaknn variasi interaksi dua arah yaitu pola interaksi siswa - guru - siswa, bahkan pola interaksi yang multi-arah. Beberapa pola interakal itu digambarkan pada halaman berikut ini.
Pola Interaksi Multi-Arah

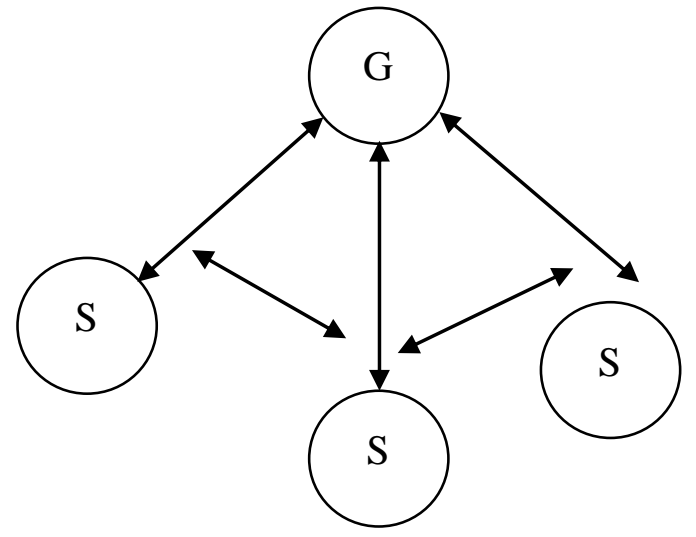


ADI WIDYA: Jurnal Pendidikan Dasar

FAKULTAS DHARMA ACARYA INSTITUT HINDU DHARMA NEGERI DENPASAR
Volume. 4, Nomor 2 Oktober 2019

ISSN: 2685-8312 (online)

ISSN: 2527-5445 (cetak

http://ejournal.ihdn.ac.id/index.php/AW
Keterampilan Mengelola Kelas (Classroom Management)

Peran guru sebagai

pengelola kelas (manager of learning) merupakan peran yang sangat penting. Bagaimanapun dalam pengajaran klasikal, efektivitas belajar mengajar sangat ditentukan oleh kepiawaian guru dalam mengatur dan mengarahkan kelas.

$\begin{array}{ccc}\text { Dalam } & \text { suatu } & \text { proses } \\ \text { pembelajaran, } & \text { guru } & \text { sering }\end{array}$
dihadapkan pada situasi kelas yang tidak menyenangkan, misalnya ada siswa yang selalu mengganggu suasana belajar dengan melontarkan kata-kata yang dapat mengganggu perhatian seluruh siswa; atau berkata "huuuuu" ketika seorang siswa bertanya atau menjawab. Hal-hal semacam itu merupakan gangguan yang dapat memengaruhi iklim belajar mengajar. Untuk mengantisipasi keadaan kelas yang kacau atau untuk mengembalikan suasana kelas pada keadaan yang normal, diperlukan keterampilan guru dalam mengelola kelas. Pengelolaan kelas adalah keterampilan guru menciptakan dan memelihara kondisi belajar yang optimal dan mengembalikannya manakala terjadi hal-hal yang dapat mengganggu suasana pembelajaran.

\section{PENUTUP}

Ketrampilan dasar merupakan keterampilan standar yang harus dimiliki setiap individu yang berprofesi sebagai guru. Keterampilan itulah yang sepintas dapat membedakan mana guru yang profesional dan mana yang bukan guru. Sama halnya dengan keterampilan seorang dokter dalam menggunakan alat suntik, atau seorang ahli bedah menggunakan pisau bedahnya. Sulit kita mengatakan bahwa ia seorang dokter, kalau ternyata tidak bisa menggunakan alat suntik, atau tidak bisa menulis resep. Keterampilan-keterampilan tersebut adalah keterampilan yang melekat pada profesinya sebagai hasil dari proses pendidikan yang diselenggarakan oleh lembaga pendidikan tertentu.

Dikaitkan dengan pembelajaran dalam konteks Kurikulum Berbasis Kompetensi, keterampilan dasar ini sangat penting untuk dikuasai oleh guru, kalau sekarang adalah kurikulum (K 13). Sebab strategi dan model pembelajaran apa pun yang digunakan efektivitasnya sangat ditentukan oleh keterampilan guru dalam pengelolaan proses pembelajaran. Ada sejumlah keterampilan yang harus dimiliki seorang guru agar dalam mengerjakan tugas profesionalnya berhasil secara optimal.

Keterampilan dasar penguatan adalah segala bentuk respons yang merupakan bagian 
ADI WIDYA: Jurnal Pendidikan Dasar

FAKULTAS DHARMA ACARYA INSTITUT HINDU DHARMA NEGERI DENPASAR
Volume. 4, Nomor 2 Oktober 2019 ISSN: 2685-8312 (online)

ISSN: 2527-5445 (cetak

http://ejournal.ihdn.ac.id/index.php/AW dari modifikasi. Tingkah laku guru terhadap tingkah laku siswa, yang bertujuan untuk memberikan informasi atau umpan balik bagi siswa atas perbuatan atau responnya yang diberikan sebagai suatu dorongan atau koreksi. Melalui keterampilan penguatan (reinforcement) yang diberikan guru, maka siswa akan merasa terdorong selamanya untuk memberikan respons setiap kali muncul stimulus dari guru; atau siswa akan berusaha menghindani respons yang dianggap tidak bermanfaat. Dengan demikian fungsi keterampilan penguatan (reinforcement) itu adalah untuk memberikan ganjaran kepada siswa sehingga siswa akan berbesar hati dan meningkatkan partisipasinya dalam setiap proses pembelajaran.

\section{DAFTAR PUSTAKA}

Ade

Irawan

dkk.2004.

Mendagangkan

Sekolah

Indonesia, Jakarta:

Carruption Watch.

Nasution S. 2009. Kurikulum dan Pengajaran. Bandung: Bina Aksara.

Sanjaya, Wina. 2004. Pengembangan Kurikulum dan Proses Pembelajaran. Bandung: San Grafika.

Sanjaya, Wina.2006. Pembelajaran dalam Implementasi Kurikulum Kompetensi. Jakarta: Kencana Predana Media Group.
Suparno. $\quad 1997 . \quad$ Filsafat Konstruktivisme dalam Pendidikan. Yogyakarta: Kanisius.

Undang-Undang No.20 Tahun 2003 tentang Sistem Pendidikan Nasional. 